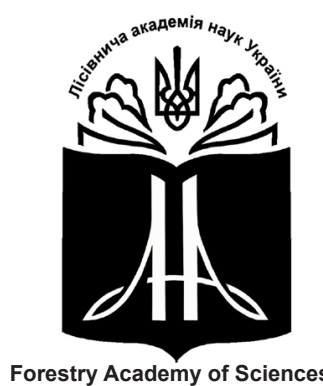

of Ukraine

Наукові праці Лісівничої академії наук України Proceedings of the Forestry Academy of Sciences of Ukraine

http://fasu.nltu.edu.ua

https://doi.org/10.15421/411803

Article received 2018.03.10

Article accepted 2018.05.31
ISSN 1991-606X print

ISSN 2616-5015 online

(a) $\triangle$ Correspondence author

Leonid Osadchuk

leosad@meta.ua

General Chuprynka st., 103, Lviv, 79057, Ukraine

УДК 630*284.2:[630*12:630*174.754]

\title{
Смолопродуктивність соснових деревостанів в Україні
}

\author{
Л.С. Осадчук' ${ }^{1}$ Л. М. Кондратюк ${ }^{2}$
}

Досліджено смолопродуктивність кліматипів сосни звичайної, які ростуть у різних лісорослинних умовах України. Встановлено найвищу смолопродуктивність дерев сосни звичайної черкаського, малополіського та київськополіського кліматипів, щзо ростуть в умовах Південного Полісся та Лісостепу. Відмінності смолопродуктивності сосни різних кліматипів дають підставу диференціювати сосняки за смолопродуктивністю $з$ урахуванням лісорослинних умов.

Підвищена біологічна смолопродуктивність черкаського та київського кліматичних екотипів свідчить про перспективність масового відбору (виділення популяцій) для селекції сосни за смолопродуктивністю. До диференціації кліматипів сосни звичайної за смолопродуктивністю призводить комплекс таких чинників: середньорічна та максимальна температура повітря, сума активних температур, тривалість сонячного освітлення, а також середньорічна сума опадів та висота місцезростання над рівнем моря.

Здійснені дослідження розподілу дерев за смолопродуктивністю в підсочуваних насадженнях Малого та Західного Полісся дають підставу стверджувати, щуо в деревостанах переважають дерева середньої категоріі смолопродуктивності. Другою за величиною є категорія дерев із пониженою, третьою - із високою смолопродуктивністю.

Ключові слова: сосна звичайна; кліматичні екотипи; мінливість смолопродуктивності; розподіл дерев за смолопродуктивністю.

Вступ. У переважній більшості природно-географічних зон України сосна звичайна (Pinus sylvestris L.) слугує основною лісотвірною породою, насадження якої виконують кліматорегулятивні, водозахисні, грунтозахисні та інші екологічні функції. Соснова живиця - екологічно чистий і біологічно відновлювальний матеріал, є цінною сировиною для отримання каніфолі, скипидару та багатьох інших хімічних продуктів. У країнах з розвиненою економікою на одну особу використовують 1,8 кг каніфолі (Stephan, 1995). Окрім традиційного застосування продуктів iз живиці, варто відзначити нові можливості іï використання у виробництві біопалива (Hodges, 1997,
Hodges, Green, 2000, Kaplan, Alma, Tutuş \& Çetinkaya, 2005) та у медицині (Dopow, Weiss, Felix \& Schmutzler, 1987, Mercieri, J. Prost \& M. Prost, 2009).

У зв'язку з багатоцільовим і комплексним використанням лісових багатств, що тепер є основною тенденцією розвитку лісогосподарського виробництва у світі, принципи якого закріплені Лісовим кодексом України, а також висвітлені у матеріалах світових конгресів і з'іздів, неухильно зростає роль і значення недеревної продукції, зокрема - заготівлі живиці (Forest code of Ukraine, 2006, Ciesla, 1998, Coppen, 1995). Вивчення смолопродуктивності сосни звичайної на рівні популяцій, що сформувалися в певних

Осадчук Леонід Семенович - дійсний член Лісівничої академії наук України, доктор сільськогосподарських наук, професор, завідувач кафедри ботаніки, деревинознавства та недеревних ресурсів лісу. Національний лісотехнічний університет України, вул. генерала Чупринки, 103, м. Львів, 79057, Україна. Тел.: +38-032-237-10-48. E-mail: leosad@meta.ua

2 Кондратюк Любов Миколаїна - асистент кафедри лісівництва. Національний лісотехнічний університет України, вул. генерала Чупринки, 103, м. Львів, 79057, Україна. Тел.: +38-067-670-34-12; E-mail: kondratyukl@meta.ua 
географічно-кліматичних умовах, є перспективним напрямом сучасного лісознавства і має як науковий, так і практичний інтерес. Зокрема, встановлення біологічної смолопродуктивності різних екотипів сосни звичайної дає змогу оцінити сировинні запаси живиці в соснових лісах України.

Об'єкти та методика досліджень. Об' $є$ 'кm дослідження - смолопродуктивність підсочених і непідсочених лісостанів кліматичних екотипів сосни звичайної. Предмет дослідження - фенотипічні, фенологічні, морфолого-анатомічні, фізіолого-біохімічні та геокліматичні особливості смолопродуктивності.

Мета досліджень - встановити величину індивідуальної смолопродуктивності у кліматипів сосни звичайної.

Для досліджень були відібрані найхарактерніші ділянки лісових насаджень, на яких закладали пробні площі. Щоб уникнути зміни певних показників, пов'язаних із щорічним приростом деревостанів, практикували здійснення одночасних досліджень на серії пробних площ, які закладені у насадженнях різних природних екотипів сосни в Україні. При цьому насадження одного екотипу підбирали таким чином, щоб вони не відрізнялися за віком, а їхні склад, тип, інші особливості були найпоширенішими для цього регіону, тобто вони відносилися до одного природного ряду розвитку певного типу деревостану. Довготривалі наукові дослідження виконували на постійних, короткотермінові - на тимчасових пробних площах, які також закладали у лісостанах, що відображають їхню типовість. Для вивчення лісівничо-таксаційних характеристик використовували загальноприйняті методики лісівничо-таксаційних досліджень для лісівництва та лісової таксації (Grom, 2005, Girs et al., 2013).

Смолопродуктивність у дерев в експлуатованих підсочкою соснових насадженнях визначали закладанням пробних площ, на яких здійснювали суцільний перелік дерев за діаметром, визначали ширину кар, кількість обходів і кількість живиці, виділеної кожним деревом. Дані виходу живиці 3 каропідновки за паузу між підновками фіксували впродовж сезону підсочки та встановлювали середнє значення.

Смолопродуктивність дерев методом мікропоранень визначали у незапідсочених насадженнях за прямою ознакою (Vysotskij, 1978, Silvanovich, Melichko, 1991) із деякими доповненнями. Для цього на пробній площі ручним або акумуляторним дрилем із спеціальним свердлом, яке не загинає волокна, на деревах наносили круглі поранення завглибшки 4-5 мм. Прозорі поліетиленові трубки закріпляли, лише заглиблюючи їх у кору. Вони не входили в камеру смоловиділення, тобто в деревину, щоб не перекривати відкриті смоляні ходи і не перешкоджати смоловиділенню 3 периферійних найактивніших шарів заболоні. Трубки щільно входили у нанесені поранення, що цілком виключало втрати живиці. Мінімальний період ви- ділення живиці тривав не менше 24 год, впродовж яких, незалежно від смолопродуктивності дерев, виділялось 90-95 \% живиці з нанесеного поранення. Через добу після встановлення трубок заміряли довжину заповненої живицею частини. За відомого внутрішнього діаметра трубок визначали подеревний вихід живиці у вагових одиницях. Визначення смолопродуктивності дерев методом мікропоранень не виявляє негативного впливу на їхню життєдіяльність.

Після 2-3-разового визначення впродовж сезону виділення живиці за отриманими в польових умовах даними, розраховували смолопродуктивність кожного дерева на пробній площі, а також середню смолопродуктивність варіантів досліджень. Для кожного варіанта досліду відбирали не менше 20-30 дерев.

Експериментальні матеріали досліджень були статистично опрацьовані згідно з прийнятими рекомендаціями (Goroshko, Myklush, \& Khomyuk, 2004) Для характеристики варіаційних рядів використано показники асиметрії та ексцесу, а приналежність чисельностей до нормального розподілу визначали за критерієм достовірності: $\mathrm{t}=\mathrm{A} / \mathrm{m}_{\mathrm{A}}>3$ та $\mathrm{t}=\mathrm{E} / \mathrm{m}_{\mathrm{E}}>3$. Під час статистичного опрацювання застосовували методи варіаційної статистики і пакет програм Microsoft Excel.

Результати та обговорення. Індивідуальну смолопродуктивність сосни варто розглядати як реалізацію спадкової програми під впливом зовнішніх чинників. Деревостани сосни звичайної, що виросли у різних лісорослинних умовах, значно відрізняються за морфологічними показниками, лісівничо-біологічними особливостями та якісними характеристиками деревини. За географічним розміщенням сосняків, кліматичні умови зростання яких $€$ подібними, виділено географічно-кліматичні екотипи сосни звичайної в лісах України (Bilous, 2002). Смолопродуктивність сосни звичайної визначали за прямою ознакою (методом мікропоранень) у насадженнях пристигаючого та стиглого віку, що ростуть у різних географічних та екологічних умовах України (табл. 1).

Отже, у стиглих насадженнях Малого Полісся смолопродуктивність змінювалася в межах 8,258,41 г/добу, пристигаючих - 6,42-6,71 г/добу. В умовах Київського Полісся цей показник, відповідно, становив 8,93 та 7,68 г/добу. Найпродуктивніші типи лісу забезпечують і значно вищу смолопродуктивність кліматипів сосни. Так, у найсприятливіших умовах для росту насаджень сосни звичайної, що знаходяться на межі Полісся і Лісостепу (Мале Полісся та Південне Полісся) в умовах свіжих суборів і сугрудів, сосна відзначається високою смолопродуктивністю. Різниця за смолопродуктивністю сосни у насадженнях Малого Полісся (ДП «Дубенське лісове господарство») та Київського Полісся (Боярська ЛДС) досягала 5,9-11,5\% і була недостовірною $\left(\mathrm{t}_{\phi}=0,66-1,25\right.$ при $\left.\mathrm{t}_{05}=2,09\right)$ як у стиглому, так і в пристигаючому віці. 


\section{Статистичні показники смолопродуктивності кліматипів сосни звичайної}

Таблиия 1

\begin{tabular}{|c|c|c|c|c|c|c|}
\hline \multirow{2}{*}{ Кліматип } & \multicolumn{3}{|c|}{ Місцезнаходження пробних площ } & \multicolumn{3}{|c|}{ Смолопродуктивність, г/добу } \\
\hline & Лісове підприємство & Широта & Довгота & $\mathrm{M}$ & $\pm_{\mathrm{M}}$ & $\mathrm{V} \%$ \\
\hline \multicolumn{7}{|c|}{ Стиглі насадження } \\
\hline \multirow{2}{*}{ Карпатський } & ДП «Осмолодське ЛГ» & $48^{\circ} 51^{\prime}$ & $24^{\circ} 14^{\prime}$ & 2,47 & 0,43 & 62,49 \\
\hline & ДП «Надвірнянське ЛГ» & $48^{\circ} 29^{\prime}$ & $24^{\circ} 24^{\prime}$ & 2,62 & 0,20 & 29,88 \\
\hline Розточанський & ПЗ «Розточчя» & $50^{\circ} 30^{\prime}$ & $24^{\circ} 45^{\prime}$ & 6,94 & 0,81 & 58,23 \\
\hline \multirow{2}{*}{ Західнополіський } & ДП «Шацьке УдЛГ» & $51^{\circ} 32^{\prime}$ & $23^{\circ} 54^{\prime}$ & 6,64 & 0,37 & 34,5 \\
\hline & ДП «Володимирецьке ЛГ» & $51^{\circ} 18^{\prime}$ & $26^{\circ} 16^{\prime}$ & 7,43 & 0,48 & 35,1 \\
\hline Центральнополіський & ДП «Овручське ЛГ» & $51^{\circ} 22^{\prime}$ & $28^{\circ} 53^{\prime}$ & 6,56 & 0,78 & 50,5 \\
\hline \multirow{3}{*}{ Малополіський } & ДП «Радехівське ЛМГ» & $50^{\circ} 08^{\prime}$ & $24^{\circ} 48$ & 8,36 & 0,54 & 28,8 \\
\hline & ДП «Дубнівське ЛГ» & $50^{\circ} 13^{\prime}$ & $25^{\circ} 44^{\prime}$ & 8,25 & 0,78 & 45,0 \\
\hline & ДП «Острозьке ЛГ» & $50^{\circ} 17^{\prime}$ & $26^{\circ} 11^{\prime}$ & 7,66 & 0,47 & 33,6 \\
\hline Київсько-Поліський & Боярська ЛДС & $50^{\circ} 18^{\prime}$ & $30^{\circ} 16^{\prime}$ & 8,93 & 0,69 & 38,8 \\
\hline Черкаський & ДП «Чигиринське ЛГ» & $49^{\circ} 07^{\prime}$ & $32^{\circ} 35^{\prime}$ & 9,70 & 0,55 & 23,2 \\
\hline Сіверськодонецький & ДП «Балаклійське ЛГ» & $49^{\circ} 26^{\prime}$ & $36^{\circ} 52^{\prime}$ & 7,98 & 0,79 & 56,2 \\
\hline \multicolumn{7}{|c|}{ Пристигаючі насадження } \\
\hline \multirow{2}{*}{ Західнополіський } & ДП «Шацьке УдЛГ» & $51^{\circ} 32^{\prime}$ & $23^{\circ} 54^{\prime}$ & 5,21 & 0,37 & 30,0 \\
\hline & ДП «Володимирецьке ЛГ» & $51^{\circ} 18^{\prime}$ & $26^{\circ} 16^{\prime}$ & 6,47 & 0,37 & 31,0 \\
\hline Центральнопо-ліський & ДП «Овручське ЛГ» & $51^{\circ} 22^{\prime}$ & $28^{\circ} 53^{\prime}$ & 5,84 & 0,59 & 48,7 \\
\hline \multirow{2}{*}{ Малополіський } & ДП «Радехівське ЛМГ» & $50^{\circ} 08^{\prime}$ & $24^{\circ} 48^{\prime}$ & 6,80 & 0,49 & 32,1 \\
\hline & ДП «Дубнівське ЛГ» & $50^{\circ} 13^{\prime}$ & $25^{\circ} 44^{\prime}$ & 6,71 & 0,78 & 58,4 \\
\hline Київсько-Поліський & Боярська ЛДС & $50^{\circ} 18^{\prime}$ & $30^{\circ} 16^{\prime}$ & 7,68 & 0,51 & 24,9 \\
\hline Черкаський & ДП «Чигиринське ЛГ» & $49^{\circ} 07^{\prime}$ & $32^{\circ} 35^{\prime}$ & 7,04 & 0,45 & 35,9 \\
\hline \multirow{2}{*}{ Нижньодніпровський } & ДП «Цюрюпинське ЛГ» & $46^{\circ} 35^{\prime}$ & $32^{\circ} 44^{\prime}$ & 6,20 & 0,66 & 49,65 \\
\hline & ДП «Очаківське ЛМГ» & $46^{\circ} 37^{\prime}$ & $31^{\circ} 24^{\prime}$ & 6,17 & 0,68 & 50,7 \\
\hline
\end{tabular}

Найвищою же смолопродуктивністю виокремлювалися насадження сосни звичайної черкаського кліматипу у свіжих суборах (9,7 г/добу), де спостерігалися сприятливі температурний і водний режими впродовж літніх місяців. Однак достовірної різниці між смолопродуктивністю сосен черкаського і малополіського кліматипів не встановлено. Соснові насадження сіверськодонецького кліматипу, що ростуть на бідних сухих піщаних і піщанокам'янистих грунтах, характеризуються дещо нижчою смолопродуктивністю (на 13,4\%) порівняно з черкаським екотипом. В умовах Північного Полісся смолопродуктивність сосни є достовірно на 25-33 \% нижчою порівняно $з$ Південним Поліссям $\left(\mathrm{t}_{\phi}=2,92-3,92\right.$ при $\left.\mathrm{t}_{05}=2,09\right)$. Для сосняків нижньодніпровського кліматипу, що ростуть на сухих грунтах суборів, відзначено вищі виходи живиці (6,17 г/добу) порівняно із сосняками, що знаходяться на перезволожених грунтах Північного Полісся. Проте згадана відмінність статистично не підтвердилась.

Смолопродуктивність у стиглому віці (90-95 років) сосни звичайної карпатського екотипу порівнювали зі смоло продуктивністю сосни, що росте в умовах Львівського Розточчя. Смолопродуктивність карпатського кліматипу на тор'янистоболотних перезволожених грунтах є дуже низькою
(2,47 г/добу) і становить лише 36\% порівняно зі смолопродуктивністю сосни у Львівському Розточчі. Дещо вищу смолопродуктивність виявлено у сосни, що росте на скельних розсипищах із нашаруванням рослинного опаду в ДП «Надвірнянське лісове господарство».

Показники смолопродуктивності кліматичних екотипів, що досліджувалися, також значною мірою залежать від географічного місцезнаходження та кліматичних умов регіону (рис. 1).

Крім цього, здійснені дослідження свідчать, що біологічна смолопродуктивність значно змінюється 3 широтою, тоді як 3 довготою при незмінній широті - змінюється у незначних межах. Коефіцієнт кореляції смолопродуктивності кліматипів сосни 3 географічною широтою становить $r=-0,87$ (без урахування нижньодніпровського кліматипу), а 3 географічною довготою $-r=0,18$.

На вплив кліматичних чинників регіонів дослідження на смолопродуктивність вказують кореляційні залежності. Прямолінійний зв'язок сильної та дуже сильної тісноти виявлено із середньорічною температурою повітря $(r=0,82)$ та сумою активних температур (САТ) вище $10 \mathrm{C}(r=0,82)$, значної тісноти зв'язок існує з максимальною температурою повітря та тривалістю сонячного опромінен- 
ня $(r=-0,58-0,64)$. Зворотній зв'язок помірної і значної тісноти виявлено 3 мінімальною температурою повітря $(r=-0,35)$, середньорічною сумою опадів $(r=-0,49)$ та тривалістю снігового покриву $(r=-0,58)$, а також висотою місцезростання над рівнем моря $(r=-0,90)$.

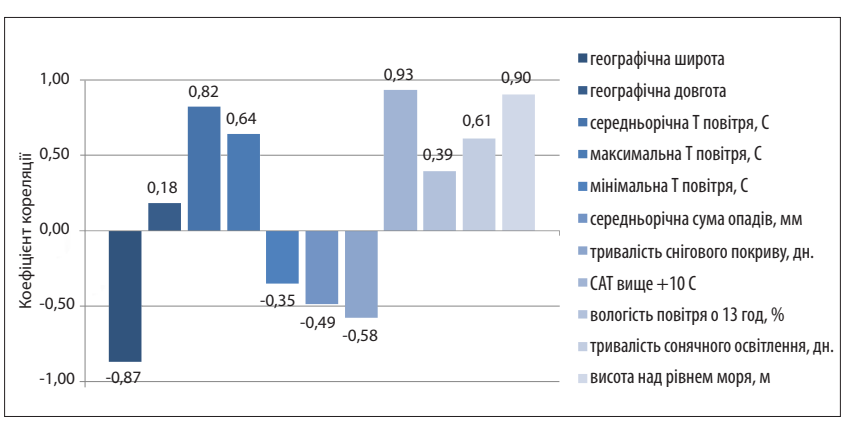

Рис. 1. Коефіцієнти кореляції смолопродуктивності кліматипів сосни звичайної з географічними координатами та середньорічними кліматичними показниками умов їх місцезростання

Таким чином, показники біологічної смолопродуктивності сосни звичайної у різних кліматичних екотипів України мають значну диференціацію. Усі ці відмінності значною мірою залежать від геогра- фічної широти місцезростання та пов'язані з кліматичними і грунтовими умовами росту насаджень, а також неоднаковою тривалістю вегетаційного періоду та сонячного освітлення, висотою над рівнем моря. Відмінності у смолопродуктивності сосни різних кліматипів дають змогу диференціювати сосняки за смолопродуктивністю з урахуванням лісорослинних умов. Існує достовірна відмінність у смолопродуктивності в межах $60 \%$ між карпатськими та 20-30\% між поліськими кліматипами і кліматипами, що ростуть у Лісостеповій зоні України та Малому Поліссі, тоді як у межах Полісся чи Лісостепової зони між кліматипами сосни достовірної відмінності не спостережено.

Основними чинниками, що позитивно впливають на мінливість смолопродуктивності сосни звичайної, є середньорічна та максимальна температура повітря, а також САТ. Суттєвий вплив на смолопродуктивність виявили такі показники клімату, як мінімальна температура повітря, середньорічна сума опадів, тривалість стояння снігового покриву.

Коефіцієнт варіації при визначенні смолопродуктивності в різних регіонах України змінювався від 26 до $58 \%$ (табл. 2).

Таблиия 2

\section{Мінливість смолопродуктивності сосни звичайної в природних та експлуатаційних насадженнях}

\begin{tabular}{lcrc}
\hline \multirow{2}{*}{\multicolumn{1}{c}{ Регіон досліджень }} & \multicolumn{3}{c}{ Коефіцієнти мінливості, \% } \\
\cline { 2 - 4 } & $\begin{array}{r}\text { біологічна } \\
\text { смолопродуктивність }\end{array}$ & $\begin{array}{r}\text { технологічна } \\
\text { смолопродуктивність }\end{array}$ & КС \\
\hline Західне Полісся & $34-35$ & $37-41$ & $34-44$ \\
Мале Полісся & $28-32$ & $39-45$ & - \\
Розточчя & $57-59$ & - & - \\
Центральне Полісся & $37-43$ & - & - \\
Правобережний лісостеп & $23-36$ & - & - \\
Лівобережний лісостеп & $55-57$ & - & - \\
Причорноморська низовина & $49-51$ & & - \\
\hline
\end{tabular}

Одержані дані свідчать про високу варіабельність індивідуальної смолопродуктивності сосни звичайної у різних умовах зростання. Потрібно відзначити тенденцію, що з просуванням з півночі на південь мінливість смолопродуктивності збільшується як у не підсичуваних, так і в підсочуваних насадженнях. Найвищу мінливість смолопродуктивності встановлено у південних регіонах (нижньодніпровський кліматип) - понад $50 \%$. Очевидно, екстремальні умови зростання (висока температура та нестача вологи) - значно диференціюють показник смолопродуктивності сосни звичайної.

Для аналітичної оцінки ймовірності розподілу дерев у підсоченому насадженні за смолопродуктивністю можна використовувати трипараметричний розподіл Вейбула (рис. 2).

Отримані результати досліджень 3 розподілу дерев за смолопродуктивністю в підсочуваних на- садженнях Малого Полісся та Західного Полісся дають підставу стверджувати, що в деревостанах переважають дерева середньої категорії смолопродуктивності, які становлять $23,7-54,4 \%$ від загальної кількості. Другою за величиною є категорія дерев із пониженою смолопродуктивністю, яка змінюється в межах від 16 до $42 \%$. Наступна за величиною - це категорія дерев із підвищеною смолопродуктивністю - 12-37\%. Кількість дерев iз дуже низькою смолопродуктивністю становить не більше $20 \%$. Найменшу кількість дерев спостережено у насадженнях з високою і дуже високою смолопродуктивністю - із максимальною кількістю до 10-12\%. При цьому на дерева із смолопродуктивністю, нижчою за середню, припадає $60 \%$ від загальної кількості дерев у насадженні.

Подальший розвиток підсочного виробництва повинен базуватися на економічних, лісівничих $\mathrm{i}$ 
технологічних засадах. Необхідно посилити економічні методи управління згаданим видом лісокористування, розробити нормативи смолопродуктивності соснових деревостанів і адаптувати ix до сучасних вимог. Потрібно використовувати лісівничо-селекційні методи для створення та формування соснових деревостанів підвищеної смолопродуктивності (Osadchuk, 2005).

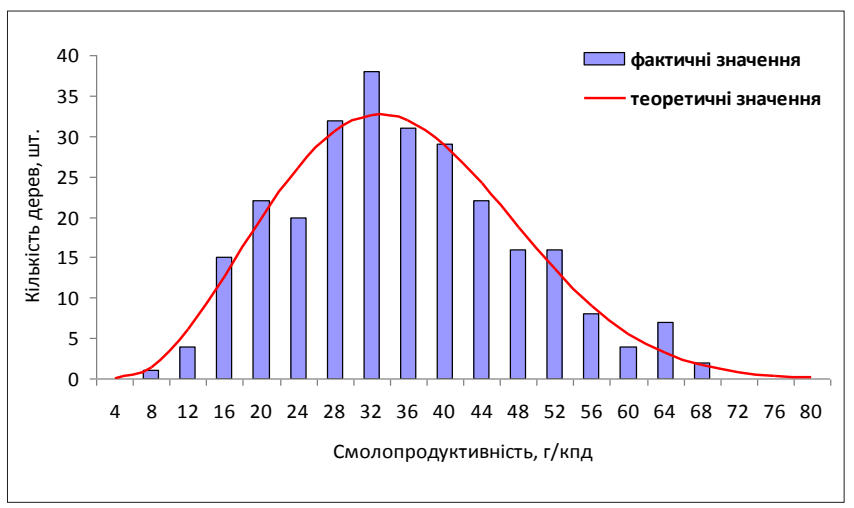

Рис. 2. Графічне відображення

статистичного моделювання розподілу Вейбула за смолопродуктивністю

Для ефективного використання існуючих соснових насаджень доцільно також залучати у підсочку й інтродуковані смолоносні види, зокрема сосну Банкса, сосну Веймутова, сосну жорстку, сосну чорну. Заготівля живиці інтродукованих видів дасть змогу покращити комплексне використання соснових лісів, а також дозволить розширити асортимент продуктів, для яких вихідним матеріалом є живиця (Osadchuk, Riabchuk \& Yuskevych, 2010). Отже, враховуючи широке застосування живиці та продуктів iii переробки, екологічну безпечність і відновлюваність ресурсу, необхідно раціонально використовувати сировинну базу хвойних порід, покращувати, розробляти й активніше впроваджувати екологічно безпечні методи підсочки та нові принципи господарювання у цій галузі.

Висновки. Показники біологічної смолопродуктивності сосни звичайної, які визначали методом мікропоранень, у різних кліматичних екотипів України мають значну диференціацію. Ці відмінності значною мірою залежать від географічної широти місцезростання та пов'язані $з$ кліматичними і грунтовими умовами росту насаджень, а також неоднаковою тривалістю вегетаційного періоду та сонячного освітлення, висотою над рівнем моря. Відмінності у смолопродуктивності сосни різних кліматипів дають підставу диференціювати сосняки за смолопродуктивністю з урахуванням лісорослинних умов. Існує достовірна відмінність у смолопродуктивності в межах $60 \%$ між карпатськими та 20-30\% між поліськими кліматипами і кліматипами, що ростуть у Лісостеповій зоні України та Малому Поліссі, тоді як у межах Полісся чи Лісостепової зони між смолопродуктивністю різних кліматипів сосни звичайної достовірної відмінності не встановлено.
Основними чинниками, що позитивно впливають на мінливість смолопродуктивності сосни звичайної, є середньорічна та максимальна температура повітря, а також сума активних температур. Негативну дію на смолопродуктивність виявляють такі показники клімату, як мінімальна температура повітря, середньорічна сума опадів і тривалість лежання снігового покриву.

Чим сприятливіші умови для росту соснових насаджень, тим нижча мінливість за показником смолопродуктивності. При цьому розподіл дерев за смолопродуктивністю в популяціях сосни у різних географічних зонах змінюється незначно і підпорядковується розподілу за функцією Вейбула.

\section{Бібліографічні посилання}

Bilous, V. (2002). Ecological types of pine in the forests of Ukraine. Proceedings of the Forestry Academy of Sciences of Ukraine, 1, 93-95 (in Ukrainian).

Ciesla, W. M. (1998). Non-wood forest products from conifers. FAO, Non-wood Forest Products. Rome.

Coppen, J. J. W. (1995). Gums, resins and latexes of plant origin // FAO, Non-wood Forest Products. Rome.

Dorow, P., Weiss, T., Felix, R., \& Schmutzler, H. (1987). Effect of a secretolytic and a combination of pinene, limonene and cineole on mucociliary clearance in patients with chronic obstructive pulmonary disease. Arzneimittelforsch, 37, 78-81.

Forest Code of Ukraine (2006). Information of the Verhovna Rada of Ukraine. Kyiv (in Ukrainian).

Girs, O. A., Manita, O. H., Myronjuk, V. V., Swingchuk, V. A., \& Berezovsky, L. M. (2013). Forest Inventory Directory. Kiev: Vinichenko Publishing House (in Ukrainian).

Goroshko, M. P., Myklush, S. I., \& Khomyuk, P. G. (2004). Biometrics. Lviv: Kamula (in Ukrainian).

Hodges, A. W., \& Green, T. C. (1997). Chemicals and biofuels from pine oleoresin. Southern Journal of Applied Forestry, 7, 21(3), 108-115.

Hodges, A.W. (2000). Continued research and development of oleoresin production from Pinus elliottii by borehole tapping. Forest Chemicals Review. Sept.-Oct., 123-128.

Kaplan, C., Alma, M. H., Tutuş, A., \& Çetinkaya, M. (2005). Engine Performance and Exhaust Emission Tests of Sulfate Turpentine and №:2 Diesel Fuel Blend. Petroleum Science and Technology, 23, 1333-1339.

Mercieri, B., Prost, J., \& Prost M. (2009). The Essential Oil of Turpentine and Its Major Volatile Fraction $(\alpha$-and $\beta$-Pinenes): A Review. Int. J. Occup. Med. Environ. Health, 22 (4), 331-342.

Osadchuk, L. S. (2005). Selection bases of increase of resin productivity pineries. Scientific bulletin of the Ukrainian State Forestry University, 15.3, 78-82 (in Ukrainian).

Osadchuk, L. S., Ryabchuk, V. P., \& Yus'kevych, T. V. (2010). Perspectives for harvesting resin in the forests of Ukraine. Proceedings of Scientific Conference: 
Sustainable forest management and rational forest management. Minsk: 2, 481-483 (in Russian).

Stephan, G. (1995). Die Kiefernharzung. Ein historischer Abriss. Beiträge für Forstwirtschaft und Landschaftsökologie, 29 (4), 177-178 (in Deutsch).

Sylvanovich, V. V., \& Melichko, A. V. (1991). Determination of resin productivity of Scots pine by micro wound method. Forest journal, 3, 24-26 (in Russian).

Vysotskij, A. A. (1978). To the technique of selection of pluses for resinous production of pine trees. Genetics, selection, seed production and introduction of forest species. Collections of scientific works, 26-29 (in Russian).

\section{Смолопродуктивность сосновых древостоев в Украине}

\section{Л.С. Осадчук', Л.Н. Кондратюк²}

Индивидуальную смолопродуктивность сосны следует рассматривать как реализацию наследственной программы под воздействием внешних факторов. Смолопродуктивность сосны обыкновенной определяли по прямому признаку (методом микроранений) в насаждениях приспевающего и спелого возраста, которые росли в разных географических и экологических условиях Украины. В спелых насаждениях Малого Полесья смолопродуктивность колебалась в пределах 8,25-8,41, в приспевающих - 6,42-6,71 г/сутки. В условиях Киевского Полесья этот показатель, соответственно, составлял 8,93 и 7,68 г/сутки. Самые продуктивные типы леса обеспечивают и значительно более высокую смолопродуктивность климатипов сосны, растущих в определенных условиях. Так, в благоприятных условиях для роста насаждений сосны обыкновенной, находящихся на границе Полесья и Лесостепи (Малое Полесье и Южное Полесье) в условиях свежих суборей и сугрудов, сосна отличается высокой смолопродуктивностью. Сосновые субори черкасского климатипа отличались наивысшей смолопродуктивностью $(9,7$ г/сут), где наблюдали благоприятные температурный и водный режимы в течение летних месяцев.

На воздействие климатических факторов регионов исследования на смолопродуктивность указывают

\footnotetext{
Осадчук Леонид Семенович - действительный член Лесной академии наук Украины, доктор сельскохозяйственных наук, профессор, заведующий кафедрой ботаники, древесиноведения и недревесных ресурсов леса. Национальный лесотехнический университет Украины, ул. генерала Чупринки, 103 г. Львов, 79057, Украина. Тел.: +38-032-237-10-48. E-mail: leosad@meta.ua

2 Кондратюк Любовь Николаевна - асистент кафедри лесоводства. Национальный лесотехнический университет Украины, ул. генерала Чупринки, 103, г. Львов, 79057, Украина. Тел.: +38-067-670-34-12; E-mail: kondratyuk1@meta.ua
}

корреляционные зависимости. Прямолинейная связь сильной и очень сильной тесноты обнаружена со среднегодовой температурой воздуха $(\mathrm{r}=0,82)$ и суммой активных температур выше $10^{\circ} \mathrm{C}(\mathrm{r}=0,82)$.3начительной тесноты связь существует с максимальной температурой воздуха и продолжительностью солнечного облучения $(\mathrm{r}=-0,58-0,64)$. Обратная связь умеренной и значительной тесноты обнаружена между минимальной температурой воздуха $(\mathrm{r}=-0,35)$, среднегодовой суммой осадков $(\mathrm{r}=-0,49)$ и продолжительностью снежного покрова $(\mathrm{r}=-0,58)$, а также высотой местопроизрастания над уровнем моря $(\mathrm{r}=-0,90)$.

Основными факторами, которые положительно влияют на изменчивость смолопродуктивности сосны обыкновенной, являются среднегодовая и максимальная температура воздуха, а также сумма активных температур. Негативное воздействие на смолопродуктивность обнаруживают такие показатели климата, как минимальная температура воздуха, среднегодовая сумма осадков и продолжительность снежного покрова.

Коэффициент вариации при определении смолопродуктивности в разных регионах Украины колебался от 26 до 58\%. Наиболее высокую изменчивость смолопродуктивности установлено в южных регионах (Нижнеднепровский климатип) более $50 \%$. Очевидно, экстремальные условия роста (высокая температура и недостаток влаги) значительно дифференцируют смолопродуктивность сосны обыкновенной.

Дальнейшее развитие подсочного производства должно базироваться на экономических, лесоводственных и технологических принципах. Необходимо усилить экономические методы управления упомянутым видом лесопользования, разработать нормативы смолопродуктивности сосновых древостоев и адаптировать их к современным требованиям. Следует использовать лесоводственноселекционные методы для создания и формирования сосновых древостоев повышенной смолопродуктивности, учитывая при этом широкое применение смол и продуктов их переработки, экологическую безопасность и восстанавливаемость ресурса. Необходимо рационально использовать сырьевую базу хвойных пород, улучшать, разрабатывать и внедрять экологически безопасные методы подсочки и новые принципы хозяйствования в этой области.

Ключевые слова: сосна обыкновенная; климатические экотипы; изменчивость смолопродуктивности; распределение деревьев по смолопродуктивности. 


\section{Resin productivity of pine forest stands in the conditions of Ukraine}

\section{Osadchuk', L. Kondratiuk ${ }^{2}$}

Individual resin productivity of Scots pine (Pinus silvestris L.) should be considered as implementation of the hereditary program under the influence of external factors. Resin productivity of Scots pine was determined on the direct basis (by the method of micro wounds) in the plantations of pre-mature and mature stands, which grew in different geographical and ecological conditions of Ukraine. In the mature stands of Small Polissya the resin productivity fluctuated within $8.258 .41 \mathrm{~g} /$ day, ripening $6,426.71 \mathrm{~g} /$ day. In the conditions of the Kyiv Polissya this indicator, respectively, was 8.93 and $7.68 \mathrm{~g} /$ day. The most productive types of forests provide significantly higher resin productivity of pine climates, growing under certain conditions. Therefore, in favorable conditions for the Scots pine stands growth on the edge of Polissya and Forest Steppe (Small Polissya and South Polissya) on fresh fairly infertile and fertile site types, the Scots pine is characterized by high resin productivity. Pine fairly infertile sites were distinguished by the highest resin productivity $(9.7 \mathrm{~g} /$ day $)$, where favorable temperature and water conditions were observed during the summer season.

The influence of regional climatic factors on the resin productivity is indicated by correlation dependences. The straight-line connection of strong

Leonid Osadchuk - full Member of the Forestry Academy of Sciences of Ukraine, Doctor of Agricultural Sciences, Professor, Head of the Department of Botany, Wood Science and Non-Wood Forest Products . Ukrainian National Forestry University. General Chuprynka st., 103, Lviv, 79057, Ukraine. Tel.: 032-237-10-48. E-mail: leosad@meta.ua

Liubov Kondratiuk - assistant of the Forestry department. Ukrainian National Forestry University, General Chuprynka st., 103, Lviv, 79057, Ukraine Tel.: +38-067-670-34-12. E-mail: kondratyuk1@, meta.ua and very strong tightness was found with the average annual air temperature $(\mathrm{r}=0.82)$ and the sum of the active temperatures above $10{ }^{\circ} \mathrm{C}(\mathrm{r}=0.82)$, a considerable connection exists with the maximum air temperature and the duration of solar irradiation. Feedback of measurable and significant tightness was detected with minimum air temperature $(\mathrm{r}=0.35)$, average annual precipitation $(\mathrm{r}=0.49)$ and snow cover duration $(\mathrm{r}=0.58)$, and height of the site above sea level $(r=0.90)$.

The main factors, which positively affects on the variability of Scots pine resin productivity, are the average annual and maximum air temperature, as well as SAT. Negative impact on resin productivity is detected by such climate indicators as minimum air temperature, average annual precipitation and duration of snow cover.

The coefficient of variation in the determination of resin productivity in different regions of Ukraine varied from 26 to $58 \%$. Higher variability of resin productivity was established in the southern regions (Lower Dnieper climatype) more than 50\%. Obviously, extreme growth conditions (high temperature and lack of moisture) significantly differentiate the resin productivity of Scots pine.

Further development of forest tapping production should be based on economic, silvicultural and technological principles. It is necessary to strengthen economic methods of management of this type of forest management, develop standards for the productivity of pine stands and adapt them to modern requirements. It is necessary to use silvicultural and selection methods for creating and forming pine stands with increased resin productivity, taking into account the wide application of resins and their processing products, ecological safety and resource recovery. It is necessary to use sustainably the raw material base of coniferous trees, improve, develop and implement environmentally friendly methods of tapping and new principles of management in this field.

Key words: Scots pine; climatype; variability of resin productivity; trees distribution by resin productivity. 